\title{
The Diaspora Phenomenon and the Welfare of Children Left Behind: A Child Rights Approach and Gender Perspective
}

\section{Wonder Muchabaiwa \\ ORCID iD: https://orcid.org/0000-0001-5684-8500}

\begin{abstract}
The rate of migration into neighbouring countries like South Africa and Botswana has continued to rise as Zimbabwe's economy continues to falter. This study explores the circumstances of children left by migrant parents and how the girl child, in particular, is more vulnerable to abuse than their male counterparts. The qualitative study interviewed 12 children (five boys and seven girls) left behind by migrant parents; three surrogate parents and four teachers in Harare Metropolitan Province. The in-depth interviews revealed that children left in the care of family members live under difficult and abusive circumstances. In many cases, the girl child assumes the role of a maid the moment her parents cross the borders. She assumes the responsibilities of running a home and this tends to compromise her studies. Some daughters of migrant parents become victims of child marriages, pointing to the gullibility of girls in such circumstances. The study argues that migration tends to expose girls to sexual predators in a society dominated by patriarchal orientation. Although children growing in foreign lands have their challenges, this study recommends that migrant parents should take their children with them as the best childcare can be realised under the custodianship of the parents.
\end{abstract}

Keywords: surrogate parents, diaspora, migrant parents, patriarchy

\section{Introduction}

This study explores the circumstances faced by children left by migrant parents, with particular interest in the circumstances of the girl child. The study 
was conducted in 2019 in the Harare metropolitan province of Zimbabwe. Migration is a global phenomenon that has tremendously affected the lives of migrants and those left in their countries of origin. Osikire (2009: 9) reveals that about half of the world's migrants are women who migrated as primary income earners. Migration remains a cause for concern as the proliferation of the phenomenon is a reality. According to the International Labour Organization (2006), the global economic, social, political and demographic trends indicate clearly that international labour migration is likely to increase. It further elaborates that globalisation has had important implications for international labour markets through Information Communication Technologies. For Africa, the intra-Africa emigration rate is about 52\% while for countries in sub-Saharan Africa this figure is close to $65 \%$, which represents the largest intra-continental movement in the world (Kohnert 2007). The apparent high emigration rates in sub-Saharan Africa are a cause for concern and this provides impetus to understand the circumstances of the children left behind by migrant parents

It is not uncommon for migrant parents to violate their children's rights by leaving them behind and abdicating some of their responsibilities. According to the African Charter on the Rights and Welfare of the Child (1999), article 19, children have the right to live with their parents. Similarly, the provisions of section 81(1d) of the Constitution of Zimbabwe stipulate that children have the right to a family and to parental care. Against this backdrop, the study argues that the challenges faced by children left behind by migrant parents take a gendered trajectory as the girl child tends to be affected by the patriarchal nature and stereotypical perceptions about femininity in African societies.

In Africa, a number of socio-economic, political, cultural and geographical factors have exerted pressure on people, causing them to migrate (Kohnert 2007). The proliferation of the migrancy phenomenon in Africa has been exacerbated by the desire to escape abject poverty and adversity caused by economic and political crises in the countries of origin. According to Lucas (2013), sub-Saharan Africa has become the lowest income earner of all the major regions in the world and has the fastest population growth, resulting in very low and unsustainable gross domestic products (GDPs) in those countries. However, because of its vibrant economy, South Africa remains the main destination for emigrants from Lesotho, Swaziland, Botswana, Mozambique and Zimbabwe (Makina 2010). South Africa was by far the single largest 


\section{Wonder Muchabaiwa}

destination country for both voluntary and involuntary migration for Zimbabweans. A study by Crush and Tevera (2010) reveals that two to three million Zimbabweans are estimated to be working and living in the diaspora. Of this total, unofficial records estimate that 1 to 1.5 million of these people live in South Africa. Sadomba (2011) postulates that Zimbabwe's unplanned land reform or redistribution had ripple effects that ultimately led to the economic collapse and political crises which pushed many Zimbabweans across borders and dispersed them all over the world in their search for employment. It should be noted that the movement by Zimbabweans separated husbands and wives, and parents and children. A survey by Crush et al. (2012) reveals that the economic hardships have forced skilled and unskilled men and women, married and unmarried, families and individuals, both young and old to migrate, from Zimbabwe. With gender demographics of migrants at $41 \%$ female and 59\% male (Makina 2010) the gender dynamics in migration reveal circumstances where both parents may migrate to other countries leaving their children in the care of relatives or friends.

\section{Conceptual Framework: The Child Rights Approach and the Gender Perspective}

The circumstances of children left behind by migrant parents can be understood more comprehensively through the lenses of the child rights approach. To understand the circumstances and challenges experienced by the girl child, the study combines the notion of gender stereotypes and child rights into one conceptual framework. The United Nations (UN 1989) Convention on the Rights of the Child (CRC) was designed to promote and protect the survival, development and well-being of children. Article 18 of the CRC states that both parents have common responsibilities for the upbringing and development of the child. Some of the fundamental child rights stipulated in the CRC include: the right to education and healthcare, protection against all forms of violence and protection from economic and sexual exploitation, among others. The decision by migrant parents to leave children behind should be in the best interest of the child or else the absent parents may expose their children to abuse and exploitation.

This study argues that the circumstances of the girl child left behind by migrant parents tends to be disconcerting because she is a minor and that she is female. According to the Beijing Plan of Action (1995), the girl child's 
rights are codified within the UNCRC and include non-discrimination, protection from harm and abuse, and full participation in the family, social and cultural life. In African societies barriers to these rights include deeply entrenched patriarchal and cultural gender stereotypes that tend to undermine the girl child's rights and agency. It is against this backdrop that some African feminists call for the revision of cultural practices (Amadiume 1987: 8; Kolawole 2002: 92; Nkealah 2006: 133) that deprive the girl child of her dignity and independence. In the same vein the liberal feminists argue that girls and women are humans whose rights should be promoted and protected. Thus, differential experiences of children left behind by migrant parents on the basis of gender become a real issue as the girl is more affected than her boy counterpart. Looking through the lenses of the child rights and gender, this study thus argues that migration has severe implications on the welfare of the girl child left behind.

\section{Research Methodology}

The study employed a qualitative research approach to guide the process of collecting, presenting and analysing data on the circumstances of children left behind in their homeland by migrant parents. Qualitative research is usually informed by the interpretivist (interpretivism) paradigm (Neuman 2014: 51). As a research paradigm, interpretivism allowed an in-depth exploration of the experiences, attitudes, feelings and perceptions on the circumstances of children left behind by migrant parents. The study thus adopted qualitative data collection methods in the form of in-depth interviews.

\section{Sampling}

Participants for this study were very difficult to locate hence snowballing and purposive sampling techniques were adopted to locate children left behind by migrant parents, surrogate parents, teachers responsible for educating such children as well as parents who had some experience in leaving children behind as they had migrated to other countries. The teachers were identified by following up at the schools of the children left behind by migrant parents. Purposive sampling is a non-probability based method where participants are selected for a specific purpose, usually because of their unique position, experience and knowledge (Baxter \& Jack 2008: 9; Cohen et al. 2007: 114). 


\section{Wonder Muchabaiwa}

Patton (2007: 181) adds that the thrust of purposive sampling is to identify information-rich sites. By implication, I selected participants who had had direct experience with children left behind by migrant parents. In-depth interviews with these key informants exposed critical information on the gender dynamics involved, the welfare and educational challenges of this group of children.

\section{Data Collection Methods}

The study utilised qualitative data gathering methods in the form of in-depth interviews to collect critical information on circumstances of children left behind by migrant parents, gender dynamics involved therein, as well as the welfare and educational challenges of girls growing in such contexts. According to Schutt (2009: 315) and Cohen et al. (2007: 228), in-depth interviewing is a qualitative method which involves open-ended, relatively unstructured questions in which the interviewer seeks information on the interviewees' feelings, experiences and perceptions of a given social phenomenon in their own terms and in the context of their situation. The study paid particular attention to practices that are bent on violating children's rights, particularly the rights of the girl child.

\section{Data Presentation and Analysis}

The study adopted an interpretive analysis model which helped in establishing emerging patterns or themes from the collected data. Gall et al. (2007: 466) and Cohen et al. (2007: 86) describe interpretive analysis as the process of examining a case study closely in order to find constructs, themes and patterns that can be used to describe and explain the phenomenon being studied. In this regard, data from interviews were segmented and categorised into the follows themes: migration and welfare of children; migration and children's educational experiences; and migration and the girl child's circumstances and schooling experiences. The circumstances of children left behind by migrant families were analysed through the lenses of child rights and of the gender conceptual framework.

\section{Ethical Considerations}

Ethics in research involves considerations such as fairness, honesty, respect for 
the integrity of individuals and the confidentiality of certain information (Schutt 2009: 72). The study sought and gained written informed consent from the research participants. In this regard before every interview, the purpose of the study, its benefits to society and how long each interview would take was explained to the participants. The participants were informed that participating in the interviews was entirely voluntary and that participants had the right to withdraw at any stage. For children, informed consent was sought from guardians or their surrogate parents. Five surrogate parents did not provide consent for the children left in their custody to be interviewed. Since the study focused on children, it was critical to maintain the confidentiality and privacy of information relating to these children. To protect the anonymity of research participants, pseudonyms were used for all the participants.

\section{Research Findings}

Data were collected through in-depth interviews with children left behind by migrant parents, surrogate parents and teachers responsible for educating these children. The study reveals that migration exposes children to abuse and exploitative practices by the parents themselves and the entrusted surrogate parents. In such exploitative circumstances, the girl child is particularly affected because of the deeply entrenched patriarchal and stereotypical perceptions on femininity in African societies. Challenges experienced by children left by migrant parents tend to extend to their schooling experiences where the academic performance of such children is greatly compromised.

\section{Migrancy and the Welfare of Children}

The tale below shows characteristics of children who were part of the research sample.

Table 1: Characteristics of children interviewed

\begin{tabular}{|l|l|l|l|l|}
\hline Name & Sex & Age & $\begin{array}{l}\text { School } \\
\text { level }\end{array}$ & $\begin{array}{l}\text { Period of Parents' } \\
\text { Absence in Years }\end{array}$ \\
\hline Tiki & Male & 12 & Grade 7 & 3 \\
\hline Cain & Male & 14 & Form 2 & 4 \\
\hline Carol & Female & 15 & Form 3 & 4 \\
\hline
\end{tabular}




\begin{tabular}{|l|l|l|l|l|}
\hline Cynthia & Female & 17 & Form 3 & 6 \\
\hline Sharon & Female & 15 & Form 3 & 6 \\
\hline Baron & Male & 12 & Grade 7 & 6 \\
\hline Chipo & Female & 16 & Form 4 & 5 \\
\hline Vuyoe & Female & 15 & Form 3 & 7 \\
\hline Danisa & Male & 11 & Grade 6 & 7 \\
\hline Ketty & Female & 16 & Form 4 & 3 \\
\hline Tom & Male & 13 & Form 1 & 3 \\
\hline Senzeni & Female & 12 & Grade 7 & 2 \\
\hline
\end{tabular}

Generally, the children most affected by migrancy are teenagers in secondary school. Children left behind by migrant parents tend to experience myriad challenges with regards to their welfare in the hands of relatives or parents' friends. An interview with Tiki, a 12-year-old boy reveals:

We are two in our family, my sister and I stay with our aunty (mother's sister). Our parents went to work in South Africa three years ago. They send money for our upkeep on a monthly basis, but the money is used for other things than our welfare. [Harare; 30 September 2019]

When Tiki was asked about the challenges they are experiencing as a result of the absence of their parents this is what he said:

The major challenge here is that we usually don't get enough food. At times we skip some meals. Most of the days we go to school on an empty stomach. What bothers me is that our parents send the money for our upkeep every month. [Harare; 30 September 2019]

When asked whether he had made his parents aware of how the money is spent by their aunt he said:

Yes, I have told them several times and all they say is that they will sort it out. The problem here is that my aunt has three children of her own and she is not married and she is not employed as well. The money sent by my parents is used for the upkeep of her children [Harare; 30 September 2019]. 
During an interview, Cain, a child also left by migrant parents explained the difficult circumstances they find themselves in as a result of the absence of their parents:

My sister and I stay with our uncle, our father's elder brother and our mother passed on when we were very young. Our father went to Botswana to look for employment some four years ago but he has since moved to South Africa. Our major challenge here is that we don't have enough food (to) eat. Our father rarely sends money for our upkeep. Because of that, our aunt sometimes prepares food and eat with her children in [behind] closed doors. At times we go school without eating. [Harare; 2 October 2019]

When asked whether he has chances to communicate with his father directly he said:

No, I have never communicated with him, I don't have any means to do so. He does not come home to see us, neither does he buy some [any] clothes for us. Uncle is always complaining about him and he seems fed up keeping us here. It's not surprising that one of these days they will kick us out of the house. To tell you the truth I am afraid and confused, I don't know what to do. [Harare; 3 October 2019].

Through obtrusive observation, it was clear that this child was neglected judging by his clothes, unkempt hair and the paleness of his skin. When interviewed, the uncle had this to say:

I am not sure what goes into people's mind when they cross the border into the diaspora. They forget they have left children [at] home. My brother does not send money for the upkeep of his children. He just does not care. He does not buy clothes for them, neither does he pay school fees for them. His friends say he has remarried and he is raising another family there, although he denies it. Everyone knows the political and economic challenges Zimbabwe is going through; I cannot raise two families. [Harare; 2 October 2019]

An interview with Carol, Cain's sister reveals the difficult circumstances of the girl child left by migrant parents: 


\section{Wonder Muchabaiwa}

I became the maid of this house the day my father crossed the border to Botswana. My aunt and her children have left all the domestic chores to me. I wake up as early as 4am every day to sweep the house and the yard. I also do all the dishes and cook for uncle and the family before I go to school. All the laundry for the whole family is my responsibility. After school, all the dishes used for lunch will be waiting for me. Because municipality water is a challenge I also go to the community borehole to fetch some water. At times Cain, my brother, helps me but I am the maid for this house. [Harare; 3 October, 2019]

When asked who is to blame for her situation, this is what she said:

First and foremost, I blame my father because he does not send money home for our up-keep. The way I see things is that I am working for the food we eat here. My brother is a bit lucky just because he is a boy. If my father was responsible, we were going to stay on our own and nobody would make me work like this. I have no time to do my homework or even play with my friends. [Harare, 7 October, 2019]

\section{Problematic Behaviours of Children left by Migrant Parents}

Another case of children left by migrant parents involved the following siblings; Cynthia who was 17 years of age and was doing form 3, Sharon who was 15 years of age and was also doing form 3 and Baron, a 12 year old boy doing grade 7 . Their parents migrated to Australia some seven years ago. These siblings live in one of the western leafy suburbs of Harare under the care of John, a caretaker who lives in a cottage behind the main house. John receives a monthly wage and his duty involves monitoring the children and maintaining the premises of the house. There is also a maid who comes on a daily basis to help with domestic chores. An interview with John reveals:

To tell the truth these children have been spoiled. The girls are involved in sexual relationships with older and married men. Most of the days some guys come to pick them (up) for a drink. The elder sister got pregnant and eloped at the age of 15. The marriage did not work, she terminated the pregnancy and decided to come back home. This 
why she is in the same grade with [as] her young sister. [Harare; 3 October 2019]

When asked whether his duties did not include monitoring the children and making sure that they do not misbehave, he said:

I have tried several times to reprimand them but they tell me that I am not their father and should mind my own business. Sometimes when no one comes to pick them (up) the elder sister comes to my cottage trying to lure me to be intimate with her. I have also discovered that they attend some nude parties that have become a nuisance in this suburb. [Harare; 7 October 2019]

When John was asked to elaborate on the nude parties he said:

There are parties that are hosted by these youngsters where those invited should come with their fiancés [partners]. When they get drunk they remove [their] clothes and start to dance while naked. They will then exchange partners, having sex with different partners. The parties are hosted at houses where parents went outside the country. They attempted to host one here and I chased them away. [Harare; 4 October 2019]

Such practices tend to expose children to infections such as HIV or other Sexually Transmitted Infections (STIs). To this effect John elaborated:

Sharon, the young sister, got infected with a severe STI, I think it was syphilis or gonorrhoea. She spent several days without going to school. The problem is that their parents send them a lot of money every month, hence they see no point in concentrating on school. Baron, the last born and only son is well-behaved but he is too young to control his sisters. [Harare, 6 October 2019].

In an attempt to have an interview with Cynthia, I was surprised when she angrily said:

Get whatever information from that useless chap (caretaker). I have no 


\section{Wonder Muchabaiwa}

time to waste with you. I am living my life. I don't care if you write an article in the newspaper about my life. You can leave our premises now before it's too late. [Harare; 5 October 2019]

In one high density suburb of Harare two children (Vuyoe \& Danisa) left by migrant parents, were interviewed. The children stayed with their married aunt had only one child. In an interview with Vuyoe she had this to say:

I find myself in very difficult circumstances in this house. I have no time to rest. After school I go to the market to help aunty sell her vegetables. I stay there until it is late. I have no time for homework or whiling up [away] with friends. The problem is that aunty is a crossborder trader as well. Because I am a girl, I am responsible for all domestic chores including bathing aunty' son and making sure he gets ready for school. Over and above this, there isn't enough food in the home, we are always hungry. [Harare, 30 September 2019]

Danisa agreed with his sister that there is always a food shortage in the home, he explained:

I am not sure how much our parents send us every month but I think aunty could be using money sent by our parent(s) for other things because we are always hungry here. We sometimes go to school on an empty stomach. At times we are sent home from school because our school fees are not paid on time. [Harare; 7 October 2019].

Children left by migrant parents tend to face myriad social and economic problems. Above all, the girl child tends to be most affected in such circumstances. Other children left by migrant parents who were interviewed also shared the same sentiments.

\section{Migrancy and Children's Schooling Experiences}

Follow up interviews with teachers who educate children with migrant parents revealed myriad challenges experienced by such children. The teachers were identified by following the children to their schools. Of much interest are the gender dynamics that see the girl child coming off worse in terms of challenges 
affecting their schooling experiences. An interview with Mr Gatsi, Vuyoe's Geography teacher, revealed:

Vuyoe's school attendance is very erratic. Usually she does not come to school on Mondays and Thursdays. She says these are the days she goes to make orders for her aunt's market. For [On] the days she attends school she comes when we are done with one or two lessons. She claims that she has to do some household chores before she comes to school. She is an above average student but her [poor] performance tends to be compounded by her erratic attendance and circumstances at her place of residence. [Harare; 11 October 2019].

When I asked about Vuyoe's behaviour the teacher said:

She used to be a good girl but because she lacks parental guidance she seems to have serious behavioural problems which include having multiple sexual relationships. She has been disciplined several times for having sexual relationships with older men. As a school, we have tried to engage the guardians but they seem not (to be) interested. We have open days when parents come to inspect their children's work and no one comes to see their work. [Harare; 12 October 2019]

As a way forward to mitigate challenges faced by children left by migrant parents the teacher suggested:

It is important that when parents decide to go abroad, they take with them their children because they are the best custodians. The proverbial saying: it takes a village to raise a children no longer works these days because the village itself is corrupt. Girl children tend to be more vulnerable to abuse because of the patriarchal nature of our society, hence they need the protection of their parents. [Harare; 12 October 2019]

Another interview with Cynthia's teacher reveals:

Parents who migrate to other countries leaving children behind make a very big mistake. For example, Cynthia's behaviour shows that she 


\section{Wonder Muchabaiwa}

lacks parental guidance. She once dropped out of school because she had fallen pregnant. This is why she is (in) the same class with [as] her sister. I heard she eloped to [with] a guy but later had a miscarriage or terminated the pregnancy and returned to their home. She is in the habit of having relationships with married men, including some teachers here. She rarely does her homework and her academic performance is very low [poor]. [Harare; 7 October 2019]

Migrancy results in parental neglect (violating children's rights) which in turn affects the behaviour of children concomitantly exposing the girl child to the male gaze. In an interview, Carol's teacher explained:

She is not spared either. She has had several cases where she fights with other girls over boyfriends. I have also heard that, although not confirmed that, there are some teachers here who sexually abuse her. One emerging phenomenon that is disturbing in this affluent suburb is that of the nude parties. I am told she is part of the gang that hosts or patron she [are guests at these] parties. For me it's terribly wrong for parents to leave children as they migrate to other countries. [Harare; 7 October 2019].

The issue of nude parties initially mentioned by the caretaker was mentioned again by the teacher and points to serious moral decay in the contemporary Zimbabwean society. The interview with Sharon's teacher, the senior lady revealed serious ramifications for leaving girl children behind as parents migrate to other countries in search of employment. She said:

Leaving children behind as parents migrate to other countries has serious implications for the girl child as hers becomes a double tragedy. She is worse affected because she is a minor and also because she is a woman [female]. I have talked to her several times and discovered that she is abused at home. Her aunt overworks her and has literally turned her into a maid. She has no time for homework or even self-study. At one point she told (me) that her uncle is in the habit of fondling her breasts without her permission. However, the uncle's indecorous behaviour seems to have stopped because I threatened to report him to the police. Given such circumstances, Sharon tends to 
perform dismally in school every term. For migrant parents, the best arrangement is to take their children with them. [Harare; 11 October 2019]

A follow up with Ketty and Tom also revealed that children left by migrant parents tend to experience problems with resources for their schooling. Ketty's clothing technology teacher explains:

Ketty struggles with learning resources. She does not have materials required for this subject. She hardly has stationery for the different subjects. If you look at her uniform, then you will know that she coming [comes] from a poverty stricken household. Our social records show that the parents divorced and both of them went into the diaspora; the father is in Botswana while the mother is in South Africa. The sad scenario is that the mother left the children in the custody of a friend who apparently abuses the few resources remitted by the mother. According to Ketty, the father does not send them anything. All I can say is that her academic performance is greatly affected by her poor socio-economic background caused by the parents' migration. [Harare; 11 October 2019]

The findings show that migration tends to have serious implications on the welfare of children and is worse still for the girl child. Parental neglect as a result of migration exposes children to sexual abuse and academic underachievement. Hence migrancy or the absence of a parent/caregiver violates the child rights as enunciated in the Constitution of Zimbabwe, African Charter on the Rights and Welfare of the Child as well as the Convention on the Rights of the Child.

\section{Discussion of Research Findings}

Children left behind in their homeland by migrant parents tend to live under very difficult circumstances due to lack of social, emotional and economic support. Parental absence thus tends to infringe on the fundamental rights of children. The study explores the nexus between migrancy and children's welfare, behavioural problems and schooling experiences. It is also important to understand how gender dynamics tend to overlap with lack of social, 


\section{Wonder Muchabaiwa}

emotional and economic support by parents. To create a holistic picture of the circumstances of children left behind by migrant parents the study utilises the child rights approach and the gender perspective as lenses for analysis.

\section{Migration and the Welfare of Children}

The decision to leave children behind as parents migrate to other countries should be in the best interest of the child. One of the critical provisions of the CRC and the African Charter on the Rights of the Child is the economic support expected from parents. The initial intention to go abroad and seek employment is meant to support children, however what happens after parents cross the border into the diaspora suggests something to the contrary. Interviews with participants revealed that children left in the custody of relatives and friends tend to experience a shortage of basic supplies such as food and clothing. The study therefore argues that migrancy tends to compromise the welfare of children. Leaving children in the hands of other people becomes an act of negligence by parents, which is a violation of the fundamental rights of the children.

What is more disturbing in the circumstances of children left by migrant parents is that the girl child tends to be more adversely affected. A case in point is where Carol says that she became the maid of the house the moment her parents crossed the border to South Africa. In most African societies, the deeply entrenched patriarchal orientation mediates people to perceive domestic chores as the primary responsibility of the girl child (Kandiyoti 1988). Such gender stereotypical perceptions can exacerbate the situation of the girl child as she tends to be emotionally and physically abused by the burden of domestic chores. According to Kolawole (2002), African feminists are fighting to revise cultural practices that are oppressive to women. Girls left behind by migrant parents are most affected because first and foremost they are minors and secondly they are girls. Violation of children's rights as a result of migration thus becomes gendered because the girl child tends to be more negatively affected.

\section{The Girl Child and Sexual Exploitation}

The study reveals that parental absence through migration tends to expose the girl child to sexual abuse and exploitation. It is therefore argued that migration 
tends to expose girl children to the male gaze compounded by patriarchal orientation and misconceptions on male sexual virility among the Shona people of Zimbabwe. The proverbial saying that it takes a village to raise a child has lost its value because the village itself has become corrupt. Men tend to take advantage of the girl child who lacks parental protection and use them for their sexual gratification. In other words, the stereotypical belief in African societies that male sexual virility can be satiated by young women (Zeitzen 2008) may explain why men seek the attention of younger women, hence the unprotected girls left by migrant parents become victims of sexual abuse. Patriarchy may also imply that a gendered sexuality is mediated where women are subordinated to the extent that females may actually lose control over their sexuality (Uchendu 2008). What is important to note here is that sexuality is socially constructed by cultural definitions and prohibitions which are relative to any given socio-cultural context. The social construction of female sexuality in African societies becomes particularly important for understanding the gullibility of the girl child to sexual abuse, especially those who lack parental protection and guidance.

It is through heterosexual relationships that African men tend to exercise their dominion over the female body. The social sanctions brought against women and girls who are not identified as attached to men in African societies show the extent to which heterosexuality is cherished and maintained through social control (Machera 2004: 166; Bourdillon 1997). The study thus argues that some men pounce on the vulnerable girl child left by migrant parents to satiate their sexual gratification. It is also important to realise that at times the girl child is pushed into exploitative sexual relationships with older and married men because of hunger and poverty. In such circumstances, the girl child may use sex as a resource in exchange for food and other needs. The feminisation of poverty thus becomes an entrenched phenomenon of most typical households with girl children left behind by migrant parents. The study therefore argues that migrancy tends to violate the rights of the girl child by exposing them to poverty, sexual abuse and exploitation. Parental migrancy may thus become a hindrance to the realisation of Sustainable Development Goals number one; end poverty in all its forms everywhere and number five; achieve gender equality and empower all women and girls by 2030 .

Findings of the study also revealed that migration by parents tends to expose the girl child to early marriage. Because such girls tend to indulge in sexual relationships prematurely, they may fall pregnant leading to early 


\section{Wonder Muchabaiwa}

marriage, as was the case with Cynthia. Early child marriage tends to deny the girl child her right to education and ultimately limits her access to productive career options.

\section{Migrancy and Children's Educational Experiences}

During the interviews with teachers, it emerged that such children tend to experience serious challenges at school. It has also been observed that under such circumstances, the girl child tends to be most severely affected by the parents' migration.

The child's socio-economic background has a strong bearing on their studies. The teachers revealed that such children tend to perform poorly in school. Some go to school on an empty stomach and this can result in loss of concentration, which may affect their academic performance. Failure to provide enough food for children is a serious violation of children's rights which in turn mediates the violation of another fundamental right of children; access to education. It was also observed that children left behind by migrant parents tend to have a sense of insecurity which also affects their self-esteem, confidence and motivation. Another issue is lack of supervision of homework by their guardians, since guardians may not concentrate on the education of their children. Because there is lack of supervision at home, children left by migrant parents tend to join some anti-school subcultural groups that engage in truancy, drug abuse, bullying and some gangs which host and attend some nude parties. Nude parties are a serious threat to the health of the child. Such a practice may affect the girl child more as she may fall pregnant and drop out of school. Generally, migration tends to violate children's right to education as children left by migrant parents lack supervision, motivation and the resources necessary for their schooling.

The academic experiences of these children left by migrant parents take a gendered trajectory. Interviews with such children revealed that girl children become overwhelmed by the burden of domestic chores as the surrogate parents are in the habit of turning them into house maids the moment their parents cross the country's border. According to Kolawole (2002), gender role socialisation culminates in the social creation of the feminine mystique; that women should be confined to domestic chores where they are expected to serve men. Such gender stereotypical perceptions are shaped by the deeply entrenched patriarchal and cultural practices in African societies. Gender stereotypical perceptions thus compromise the education of the girl child as 
she lacks enough time for homework or self-study. More so, by the time the girl child arrives at school she is already exhausted by the domestic chores hence her concentration in class is greatly affected. The burden of domestic chores can be perceived as child labour which is a serious violation of the fundamental rights of children.

The academic performance of the girl child can be greatly affected by sexual harassment and exploitation at school. An interview with a senior teacher at one school revealed that such girls may drop out school when they fall pregnant because they tend to have multiple sexual relationships. Sexual relationships with older men including teachers may limit their ability to concentrate on schoolwork. Furthermore, multiple sexual partners may expose the girl child to STIs including HIV/AIDS which may keep them away from school. In this regard, the retention capacity of children in school becomes gendered.

\section{Conclusion}

The main reason why children tend to misbehave is lack of parental guidance and protection. For the girl child, this is further compounded by the patriarchal nature of African societies which perceive women as inferior to men and whose existence is perceived as being to serve the needs of men. The broader picture here is that migrancy tends to affect the welfare of children and the girl child in particular.

\section{Recommendations}

Although children growing up in foreign land have their challenges, this study recommends that migrant parents should take their children with them as the best child care can be realised under the custodian of parents. There is also a need to conduct workshops that will assist to deconstruct gender stereotypical perceptions in men so that they can uphold the rights of the girl child. Another long-term recommendation is to mainstream gender issues in different subject areas from primary school level to tertiary education level. Lastly, the state should institute prohibitive penalties for men who sexually abuse children. The violation of children' rights should be categorised as a serious crime. 


\section{References}

African Charter on the Rights and Welfare of the Child (ACRWC), www.acerw.org/the charter

Amadiume, I. 1987. Male Daughters and Female Husbands: Gender and Sex in an African Society. London: Zed Ltd.

Baxter, P. \& S. Jack 2008. Qualitative Case Study Methodology: Study Design and Implementation for Novice Researchers.

http://www.nova.edu/sss/QR/OR.13-4/baxter.pdf

Bourdillon, M. 1997. The Shona Peoples. Revised Edition. Gweru: Mambo.

Cohen, L., L. Manion \& K. Morrison 2007. Research Methods in Education. London: Routledge. https://doi.org/10.4324/9780203029053

Crush, J. \& D. Tevera 2010. Zimbabwe's Exodus: Crises, Migration, Survival. Cape Town: SAMP

Gall, M., J.P. Gall \& W.R. Borg 2007. Educational Research: An Introduction. Boston: Pearson, Allyn and Bacon.

ILO 2006a. The End of Child Labour: Within Reach: Global Report under the Follow-up to the ILO Declaration on Fundamental Principles and Rights at Work. Geneva: ILO.

Kandiyoti, D. 1988. Bargaining with Patriarchy. Gender and Society 2,3:274 290. https://doi.org/10.1177/089124388002003004

Kohnert, D. 2007. African Migration to Europe: Obscured Responsibilities and Common Misconceptions. Hamburg: German Institute of Global and Area Studies: Working Paper, No. 49pp.7.

https://doi.org/10.2139/ssrn.2124906

Kolawole, M.N. 2002. Transcending Incongruities: Rethinking Feminism and Dynamics of Identity in Africa. Agenda 17,54: 72 - 98.

Machera, M. 2004. Opening a Can of Worms: A Debate of Female Sexuality in the Lecture Theatre. In Arnfred, S. (ed.): Rethinking Sexualities in Africa. Uppsala: Nordiska Afrikainstutet.

Makina, D. 2010. Zimbabwe in Johannesburg. In Crush, J. \& D. Tevera (eds.): Zimbabwe's Exodus: Crisis, Migration, Survival. Ottawa: IDRC.

Neuman, W.L. 2014. Social Research Methods: Qualitative and Quantitative Approaches. $7^{\text {th }}$ Edition. Essex: Pearson Education.

Nkealah, N.N. 2006. Conceptualising Feminisms in Africa: The Challenges Facing African Women Writers and Critics. English Academy Review 23,1:133 - 141. https://doi.org/10.1080/10131750608540431 
Oyěwùmí, O. 2004. Conceptualising Gender: Eurocentric Foundations of Feminist Concepts and the Challenge of African Epistemologies. In Arnfred, S (ed.): African Gender Scholarship: Concepts, Methodologies and Paradigms. Dakar: CODESRIA.

Osikire, A.B. 2009. Migration and Development in Nigeria. Geneva: IOM.

Patton, M. 2007. Qualitative Research and Evaluation Methods. London: Sage Publications. Routledge.

Sadomba, W.Z. 2011. War Veterans in Zimbabwe's Revolution: Challenging Neo-colonialism and Settler and International Capital. Harare: Weaver Press.

Schutt, R.K. 2007. Research Methods in Education. Boston: Sage Publications. Uchendu, E. 2008. Masculinities in Contemporary Africa. Dakar: CODESRIA. United Nations (UN) 1989. Convention on the Rights of the Child. http://www2.ohchr.org/english/law/crc.htl

Zeitzen, M.K. 2008. Polygamy: A Cross Cultural Analysis. New York: Berg. Zimbabwe's 2013 Constitution. www.constituteproject.org/constitution/Zimawe.

Dr. Wonder Muchabaiwa Lecturer Department of Educational Policy Studies and Leadership Midlands State University Gweru wonmuchabaiwa@gmail.com muchabaiwaw@staff.msu.ac 